\title{
Does the nutrient stoichiometry of primary producers affect the secondary consumer Pleurobrachia pileus?
}

\author{
Katherina L. Schoo • Nicole Aberle • \\ Arne M. Malzahn · Maarten Boersma
}

Received: 19 December 2008/ Accepted: 26 June 2009

(C) Springer Science+Business Media B.V. 2009

\begin{abstract}
We investigated whether phosphorus limitations of primary producers propagate upwards through the food web, not only to the primary consumer level but also onto the secondary consumers' level. A tri-trophic food chain was used to assess the effects of phosphorus-limited phytoplankton (the cryptophyte Rhodomonas salina) on herbivorous zooplankters (the copepod Acartia tonsa) and finally on zooplanktivores (the ctenophore Pleurobrachia pileus). The algae were cultured in phosphorusreplete and phosphorus-limited media before being fed to two groups of copepods. The copepods in turn were fed to the top predator, $P$. pileus, in a mixture resulting in a phosphorus-gradient, ranging from copepods having received only phosphorus-replete algae to copepods reared solely on phosphoruslimited algae. The $\mathrm{C}: \mathrm{P}$ ratio of the algae varied significantly between the two treatments, resulting in
\end{abstract}

K. L. Schoo $(\bowtie) \cdot$ N. Aberle · A. M. Malzahn ·

M. Boersma

Alfred-Wegener-Institut für Polar- und Meeresforschung,

Biologische Anstalt Helgoland, Postbox 180, 27483

Helgoland, Germany

e-mail: Katherina.Schoo@awi.de

\section{K. L. Schoo}

Leibniz Institute of Marine Sciences, IFM-Geomar, Düsternbrooker Weg 20, 24105 Kiel, Germany

M. Boersma

GKSS-Research Centre, Institute for Coastal Research, Max-Planck-Straße 1, 21502 Geesthacht, Germany higher $\mathrm{C}: \mathrm{P}$ ratios for those copepods feeding on phosphorus-limited algae, albeit with a significance of 0.07 . The differences in the feeding environment of the copepods could be followed to Pleurobrachia pileus. Contrary to our expectations, we found that phosphorus-limited copepods represented a higher quality food source for $P$. pileus, as shown by the better condition (expressed as nucleic acid content) of the ctenophore. This could possibly be explained by the rather high $\mathrm{C}: \mathrm{P}$ ratios of ctenophores, their resulting low phosphorus demand and relative insensitivity to $\mathrm{P}$ deficiency. This might potentially be an additional explanation for the observed increasing abundances of gelatinous zooplankton in our increasingly phosphorus-limited coastal seas.

Keywords Phosphorus limitation ·

Ctenophores - Ecological stoichiometry .

Marine food webs - Gelatinous zooplankton ·

Trophic transfer

\section{Introduction}

Consumers habitually face the problem of nutritional imbalances, as the nutrient content of their prey does not always meet their requirements, leading to a mismatch between supply and demand (Sterner and Elser 2002). Specifically, in the relationship between primary producers and herbivores, nutrients such as 
nitrogen $(\mathrm{N})$ and phosphorus $(\mathrm{P})$ are often limiting, as there is a surplus of carbon in plants (White 1993). Carbon is of course needed as an energy source, and hence it will be respired through the food web, but as a result many consumers will have more problems meeting their nutrient requirements than their energy requirements. Furthermore, the stoichiometry of primary producers (i.e., the balance between different nutrients) is highly variable due to the changing balance between light and nutrients and often reflects the changing nutrient availability of the environment (Sterner et al. 1998). Therefore, for many consumers food may be of varying but generally poor quality. In contrast to their prey, animals are much more homeostatic (i.e., they maintain a constant body composition), and their nutrient stoichiometry should therefore be only weakly affected, if at all, by changes in the nutrient stoichiometry of their food (Elser et al. 2000). This herbivore homeostasis has led to the prediction that food quality effects are not passed on to higher trophic levels beyond the herbivore, as the nutrient limitation of the primary producers would be buffered by the herbivorous consumer (Sterner and Elser 2002). Secondary consumers should subsequently not be strongly affected by food quality at the primary producer-herbivore interface. However, keeping homeostasis is not without costs, and many studies have shown that herbivores actually perform much worse in food that is limited in phosphorus (Urabe et al. 1997; Elser et al. 2001) or nitrogen (Van Nieuwerburgh et al. 2004). Thus, the effect of nutrient limitation results in lower densities and potential food shortage for secondary consumers. Hence, the expectation is that the low food quality experienced by primary consumers should translate in a quantity effect on higher trophic levels (Sterner and Elser 2002).

It is, however, becoming more and more apparent that nutrient homeostasis of primary consumers is less than perfect. Herbivorous zooplankters are not always capable of maintaining a strict homeostasis when faced with changes in nutrient stoichiometry of their food source, and their nutrient content changes accordingly (Malzahn et al. 2007a). Food quality effects at the bottom of the food chain can thus change the stoichiometry of the consumers and hence may be passed on through the food chain as quality effects. As an example, carbon to phosphorus ratios of the freshwater cladoceran Daphnia can vary by a factor of two (Plath and Boersma 2001; Boersma and
Kreutzer 2002). This implies that not only the quantity but also the quality of zooplankters as food source for their predators could be affected. Consequently, higher trophic levels could in turn be faced with food of different nutrient ratios, and the quality effect of the primary producers could be transferred higher up the food chain. This aspect has long been neglected in the literature, and only very few studies have addressed the possible effects of varying phosphorus levels in primary producers on higher trophic levels (Malzahn et al. 2007a; Boersma et al. 2008; Dickmann et al. 2008; Frost et al. 2008). Only recently, Malzahn et al. (2007a) showed in an experiment extending over three trophic levels that phosphorus limitation on primary producers affects the physiological condition of planktivorous fish larvae and that severe phosphorus limitations in algae can be traced to secondary consumers.

We therefore set out to further our knowledge on nutrient limitations propagating upwards through the food web in the form of food quality and investigate the effects of phosphorus limitation in primary producers on higher trophic levels. Hence, we studied an artificial tri-trophic food chain, with the ctenophore Pleurobrachia pileus as the secondary consumer. In contrast to fish (from the aquaculture literature), not much is known about the body composition of ctenophores. Even though the work of Kremer and co-workers is substantial when it comes to carbon, nitrogen and biomolecules (Kremer 1977, 1982; Kremer et al. 1986; Youngbluth et al. 1988), the only study that we are aware of also including phosphorus (Borodkin and Korzhikova 1991) suggest that the C:P ratio of ctenophores can be as low as 83 (molar), and hence the phosphorus requirement of $P$. pileus should be high. Based on this, we expected that P-limited copepods would be a food source of very poor quality for Pleurobrachia pileus.

\section{Materials and methods}

We designed a tri-trophic experiment consisting of a primary producer, the cryptophyte Rhodomonas salina, a primary consumer, the copepod Acartia tonsa, and a secondary consumer, the ctenophore Pleurobrachia pileus. We chose $\mathrm{P}$ as the nutrient under investigation as gradients of P-limitation are stronger in algae growing in different media, and 
therefore experimentally easier to manipulate. More importantly, however, is that $\mathrm{P}$ can be the limiting nutrient in coastal seas (Elser et al. 2007; Vermaat et al. 2008), and it has been observed that the phytoplankton in the German Bight is P-limited in summer (van der Zee and Chou 2005).

\section{Primary producers}

Stock cultures of the cryptophyte Rhodomonas salina were cultivated in $\mathrm{f} / 2$ medium (Guillard and Ryther 1962). The water used during the experiment was taken from the North Sea on one single occasion. The water was filtered through a sterile $0.2 \mu \mathrm{m}$ filter and stored dark and cold until use. For the experimental treatments, $R$. salina was cultured in nutrient replete medium and in medium without added $P$. The nutrient replete medium consisted of natural seawater enriched with $\mathrm{f} / 2$ nutrients containing $36.3 \mu \mathrm{mol} \mathrm{L} \mathrm{L}^{-1}$ $\mathrm{NaH}_{2} \mathrm{PO}_{4}$, following Guillard and Ryther (1962). The $\mathrm{P}$-limited treatment consisted of $\mathrm{f} / 2$-enriched seawater without the addition of any phosphorus $(-\mathrm{P})$. The algae had access only to the $\mathrm{P}$ contained in the natural seawater at the time of filtration $\left(1.4 \mu \mathrm{mol} \mathrm{L}{ }^{-1}\right)$. Experimental algae were kept at $17^{\circ} \mathrm{C}$ under a $16: 8 \mathrm{~h}$ light:dark (L:D) cycle.

Preliminary tests on algal growth rates under experimental conditions showed $\mathrm{P}$ limitation of $R$. salina with the P-deficient medium after 4 days. Algal densities in the stock solution were determined with a CASY cell counter (Schärfe System CASY Cell Counter and Analyser System). To ensure constant food quality, new cultures of $R$. salina were inoculated daily for both treatments with a starting concentration of $0.2 \times 10^{6}$ cells $\mathrm{mL}^{-1}$ for the $\mathrm{f} / 2$ treatment and $0.3 \times 10^{6}$ cells $\mathrm{mL}^{-1}$ for the $-\mathrm{P}$ treatment. After the predefined growth period of 4 days, algae were harvested at densities of $\sim 1.5 \times 10^{6}$ cells $\mathrm{mL}^{-1}$ for the $\mathrm{f} / 2$ treatment and $1.0 \times 10^{6}$ cells $\mathrm{mL}^{-1}$ for the $-\mathrm{P}$ treatment.

\section{Primary consumers}

Copepod eggs were obtained from a laboratory culture of the calanoid copepod Acartia tonsa. For the production of eggs, animals were kept in filtered natural seawater (salinity 31 ) in a $200-\mathrm{L}$ cylindrical tank on a $16: 8 \mathrm{~h} \mathrm{~L}: \mathrm{D}$ cycle at $18^{\circ} \mathrm{C}$. The copepods were fed a mixture of the algae Rhodomonas salina and the heterotrophic flagellate Oxyrrhis sp. Eggs were siphoned off the bottom of the tank daily and stored in an airtight container in the dark at $4{ }^{\circ} \mathrm{C}$ until use.

When needed, these eggs were incubated in fresh seawater in 4-L plastic bags at a density of about 3,000 individuals per litre. The hatching rate was around $25 \%$. Copepods were first fed $24 \mathrm{~h}$ after hatching, $48 \mathrm{~h}$ after the addition of the eggs to the water in the plastic bags. In order to avoid changes in the phosphorus content of the algae during their incubation with the copepods, the eggs were incubated in phosphorus-free artificial seawater, adjusted to a salinity of 31 (salt: hw Marinemix, www.hwwiegandt.de). Copepods were fed 10,000 cells of Rhodomonas per individual and day, which is considered to be ad libitum for larval stages ( $>1 \mathrm{mg} \mathrm{C} \mathrm{L}^{-1}$ ). Copepods were fed the same amount of algal cells for each treatment to avoid food quantity effects. To guarantee a steady supply of food at constant quality for the secondary consumer, the ctenophore Pleurobrachia pileus, two new bags of copepods were started each day.

The copepods grown on P-limited algae displayed a delayed development resulting in a time-lag of $\sim 1$ day when compared to the copepods reared on $\mathrm{f} / 2$ algae. Therefore, P-limited copepods were harvested on day 8 after hatching, when the majority had reached the sixth naupliar stage, and $\mathrm{f} / 2$ copepods were 1 day younger. This ensured that copepods from different treatments were in the same developmental stage and had the same size. Copepods were fed to the ctenophore along a $\mathrm{P}$ gradient at a concentration of 0.5 individuals $\mathrm{mL}^{-1}$. This amount is above the densities reported for food saturation in ctenophores (Greve 1972; Reeve et al. 1978; Gibbons and Painting 1992), which was confirmed by the fact that some copepods were still present in all ctenophore containers $24 \mathrm{~h}$ after feeding.

\section{Secondary consumer}

The ctenophore Pleurobrachia pileus was obtained from Helgoland Roads, North Sea ( $\left.54^{\circ} 11^{\prime} \mathrm{N}, 7^{\circ} 53^{\prime} \mathrm{E}\right)$. $P$. pileus is an ambush predator, catching its motile prey in lateral filaments on its tentacles (Greve 1970; Gibbons and Painting 1992). This feeding mechanism is unselective for actively swimming prey (Fraser 1970). Individuals were transferred to flow-through tanks and kept at ambient water temperature in filtered 
seawater. Individuals were starved for 5 days prior to the first feeding in the experiment. Only ctenophores of the same size range $(10-15 \mathrm{~mm})$ were used in the experiment. For the duration of the experiment, each individual $P$. pileus was kept in a separate $1 \mathrm{~L}$ glass bottles containing filtered seawater. Water was changed daily prior to feeding to remove most of the uneaten food organisms. P. pileus were fed copepods along a P-gradient, resulting in five treatments. The treatments were randomly assigned to 50 ctenophores, ten replicates for each of the five feeding treatments. The copepods were mixed prior to being fed to $P$. pileus, resulting in the following regimes: at the extreme ends of the P-gradient the ctenophores were fed only copepods from the $\mathrm{f} / 2$ or the $-\mathrm{P}$ treatment, respectively; three other treatment groups received 75,50 and $25 \%$ of the $\mathrm{f} / 2$-reared copepods, and 25,50 and $75 \%$ of -P-reared copepods to result in the amount of 500 copepods per ctenophore day ${ }^{-1}$. $P$. pileus were fed daily for 9 days, after which the ctenophores were harvested and first frozen at $-80^{\circ} \mathrm{C}$ and thereafter freeze-dried, weighed and kept in a desiccator until analysis.

\section{Analytical procedures}

For the analysis of carbon content of the algae, $\sim 4 \times 10^{6}$ cells were filtered onto pre-combusted and washed Whatman GF/F filters. For the analysis of copepod carbon, 50 individuals were counted into tin capsules. The carbon content of the samples was measured with a Fisons EA 1108 CHN analyser. Phosphorus was analysed as orthophosphate, according to the method described by Grasshoff et al. (1999), following oxidative hydrolysis. The samples were treated with an oxidation agent $\left(\mathrm{K}_{2} \mathrm{~S}_{2} \mathrm{O}_{8}, \mathrm{H}_{3} \mathrm{BO}_{3}\right.$, $\mathrm{NaOH}$ in distilled water) under high pressure and at high temperature $\left(120^{\circ} \mathrm{C}\right)$ in an autoclave to convert the phosphorus compounds to the ortho-phosphate form. Molybdate-antimony-solution (containing ammonium molybdate $\left(\mathrm{NH}_{4}\right)_{6} \mathrm{Mo}_{7} \mathrm{O}_{24} \times 4 \mathrm{H}_{2} \mathrm{O}$, antimony potassium tartrate $\left.\mathrm{K}(\mathrm{SbO}) \mathrm{C}_{4} \mathrm{H}_{4} \mathrm{O}_{6} \times 0,5 \mathrm{H}_{2} \mathrm{O}\right)$ and ascorbic acid were added, and the P-content measured photometrically. For the analysis of carbon and P-content of Pleurobrachia pileus, pulverized tissue homogenate was used.

Dry weight (or somatic growth) is not a useful response variable in this case for several reasons. First, as we could not work with a cohort of animals of completely equal size and age, initial weight could not be established accurately enough, and hence the variation in computed growth rates would probably be much larger than any expected effect. Secondly, dry weight in gelatinous zooplankton is mainly determined by the salt in the water of the body cavities, thus does not give an accurate estimate of the growth in biomass. Consequently, we used the carbon content per dry weight as an indicator for physiological condition. Animals with a higher $\mathrm{C}$ to dry weight ratio have a better physiological condition, as was observed by for example Daly (2004). Furthermore, the nucleic acid content of the animals was also established. The techniques to determine the amounts of RNA and DNA in animal tissue are well established, and using the amount of nucleic acids RNA and DNA in the individual organisms as a measure of overall physiological condition, and as a proxy for growth, is commonly used in fisheries biology (e.g., Clemmesen et al. 2003). In many studies, a ratio between the RNA and the DNA content of animal tissue is used, under the rationale that DNA content as a constitutive component of the cell should be more constant relative to RNA, which should be higher under active growth. A high RNA to DNA ratio is therefore indicative of growth and a good physiological condition. Ctenophores are known to react to adverse conditions by changes in size (Kremer 1977). This means that most likely, they lose complete cells, with both DNA as well as RNA content. Indeed, recent work by Hamer (2008) showed that the RNA:DNA ratio in the ctenophore Mnemiopsis leidyi was more or less constant, even after many days of starvation, whereas the concentrations of RNA and DNA were much more responsive. Therefore, in this study we used the absolute amounts of RNA and DNA in the tissue of the individuals as indicators for animal physiological condition (Ferron and Leggett 1994; Parslow-Williams et al. 2001; Gorokhova 2003). The method used for the nucleic acid analysis was from Clemmesen et al. (2003) with some modification after the determination of the protocol for the extraction of nucleic acids from ctenophore tissue.

Freeze-dried tissue was pulverized using a pellet pestle and rehydrated in $400 \mu \mathrm{L}$ Tris-SDS buffer (Tris $0.05 \mathrm{~mol} \mathrm{~L}^{-1}, \mathrm{NaCl} 0.01 \mathrm{~mol} \mathrm{~L}^{-1}$, EDTA $0.01 \mathrm{~mol} \mathrm{~L}^{-1}$, sodium dodecyl sulphate (SDS) $0.005 \%$ ) for $25 \mathrm{~min}$. Glass beads (2 $\mathrm{mm}$ and 
$0.17-0.34 \mathrm{~mm}$ diameter) were added, and the tubes shaken in a Retsch MM 301 cell-mill for $15 \mathrm{~min}$. The homogenate was centrifuged (Sartorius Sigma $3-18 \mathrm{~K} ; 8 \mathrm{~min}, 3,800 \mathrm{~g}, 4^{\circ} \mathrm{C}$ ), and $130 \mu \mathrm{L}$ of the supernatant used for analysis.

The amount of nucleic acids was determined fluorometrically in a microtiter fluorescence reader (Fluoroskan Ascent) using the fluorophor ethidiumbromide (EB). Total nucleic acids were measured first. Subsequently, RNAse was added to the samples in order to digest the RNA. After the enzyme treatment (30 min at $37^{\circ} \mathrm{C}$ ), the remaining DNA was measured. The RNA fluorescence was calculated by subtracting the DNA fluorescence from the total nucleic acid fluorescence. RNA calibrations were set up at each measurement day. The DNA concentrations were calculated using the relationship between RNA and DNA fluorescence described by Le Pecq and Paoletti (1966).

\section{Results}

Primary producer and primary consumer

Algal molar C:P ratios varied significantly between treatments $\left(\mathrm{f} / 2 \sim 230,-\mathrm{P} \sim 430\right.$; ANOVA $F_{1,18}=$ 10.75; $P<0.004$; Fig. 1). The results confirm that the $-\mathrm{P}$ growth medium really was limited in phosphorus; the natural seawater contained just enough $\mathrm{P}$ to enable the algae to grow. The molar C:P ratio of

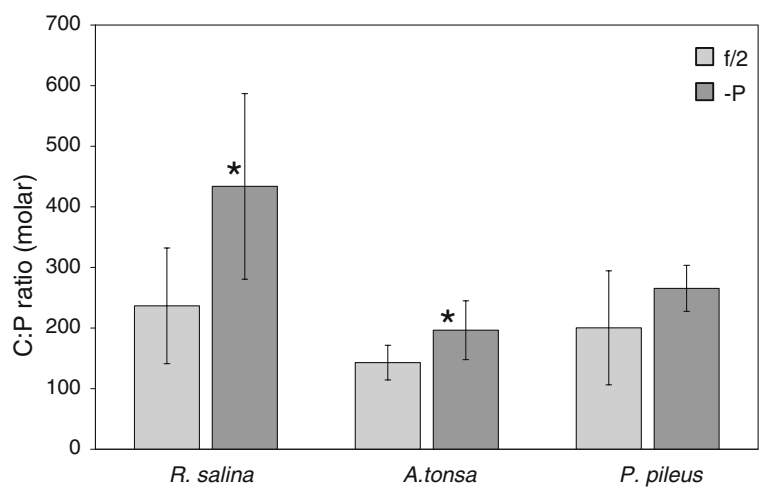

Fig. 1 Molar C:P ratios of Rhodomonas salina $(n=10)$, Acartia tonsa $(n=7)$ and Pleurobrachia pileus $(n=7)$ in a nutrient-replete (f/2) and phosphorus-limited (-P) environment. Asterisk marks significant difference $(P<0.05$ for $R$. salina, $P=0.07$ for $A$. tonsa) from the other treatment of the given species. Error bars: standard deviation the copepods also showed differences between treatments, which were significant at $P=0.07$ (f/2 $\sim 140, \quad-\mathrm{P} \sim 195 ;$ ANOVA $F_{1,10}=4.06$; $P=0.07$; Fig. 1).

Secondary consumer

The differences in the C:P ratios of $P$. pileus cultured on the extremes of the food gradient were not significant (Fig. 1), but were significantly higher than those for their food (ANOVA $F_{1,17}=6.60$; $P=0.02$ ), which was mainly caused by the differences between $f / 2$ copepods and ctenophores, with much lower C:P values for the copepods. As expected for the reasons mentioned earlier, dry weight of Pleurobrachia pileus was not significantly affected by the food they received (Fig. 2a), nor was there a clear pattern of $\mathrm{C}: \mathrm{P}$ ratios of the $P$. pileus individuals over the gradient (Fig. 2c).

$P$. pileus fed a diet consisting solely of P-limited copepods ( $0 \%$ treatment) showed the highest values of carbon per dry weight (Fig. 2b; linear regression, $\left.y=4.253-0.015 x ; r^{2}=0.36 ; P=0.001\right)$. Furthermore, both the DNA content $\left(\mu \mathrm{g} \mathrm{mg} \mathrm{DW}^{-1}\right.$ ) (Fig. $2 \mathrm{~d}$; linear regression, $y=0.294-0.002 x ; \quad r^{2}=0.18$; $P=0.01)$ and the RNA content of the experimental animals (Fig. 2e; linear regression, $y=1.249-$ $\left.0.009 x ; r^{2}=0.18 ; P=0.01\right)$ showed a significantly negative relationship with the percentage of $f / 2$ copepods in their food. The content of RNA and DNA in individuals were highly correlated $\left(r^{2}=0.98\right)$. These results indicate a simultaneous loss of both nucleic acids related to the amount of $\mathrm{f} / 2$ copepods in their diet (Fig. 2 d, e), and hence the ratio between RNA and DNA concentration of the experimental $P$. pileus individuals did not show significant change over the experimental gradient (Fig. 2f). The RNA content ( $\mu \mathrm{g} \mathrm{mg} \mathrm{DW}^{-1}$ ) of the animals in the starvation group (mean value $0.4 \mu \mathrm{g}$ RNA mg DW ${ }^{-1}$ ) was lower than that of the fed individuals. No significant correlation was found between dry weight of the animals and their biochemical composition (data not shown).

Even though the amount of explained variation in the significant relationships is modest, all physiological condition indicators point in the same direction: copepods that were grown on P-limited algae represent a food source of higher quality for Pleurobrachia pileus compared to those fed P-replete algae. 

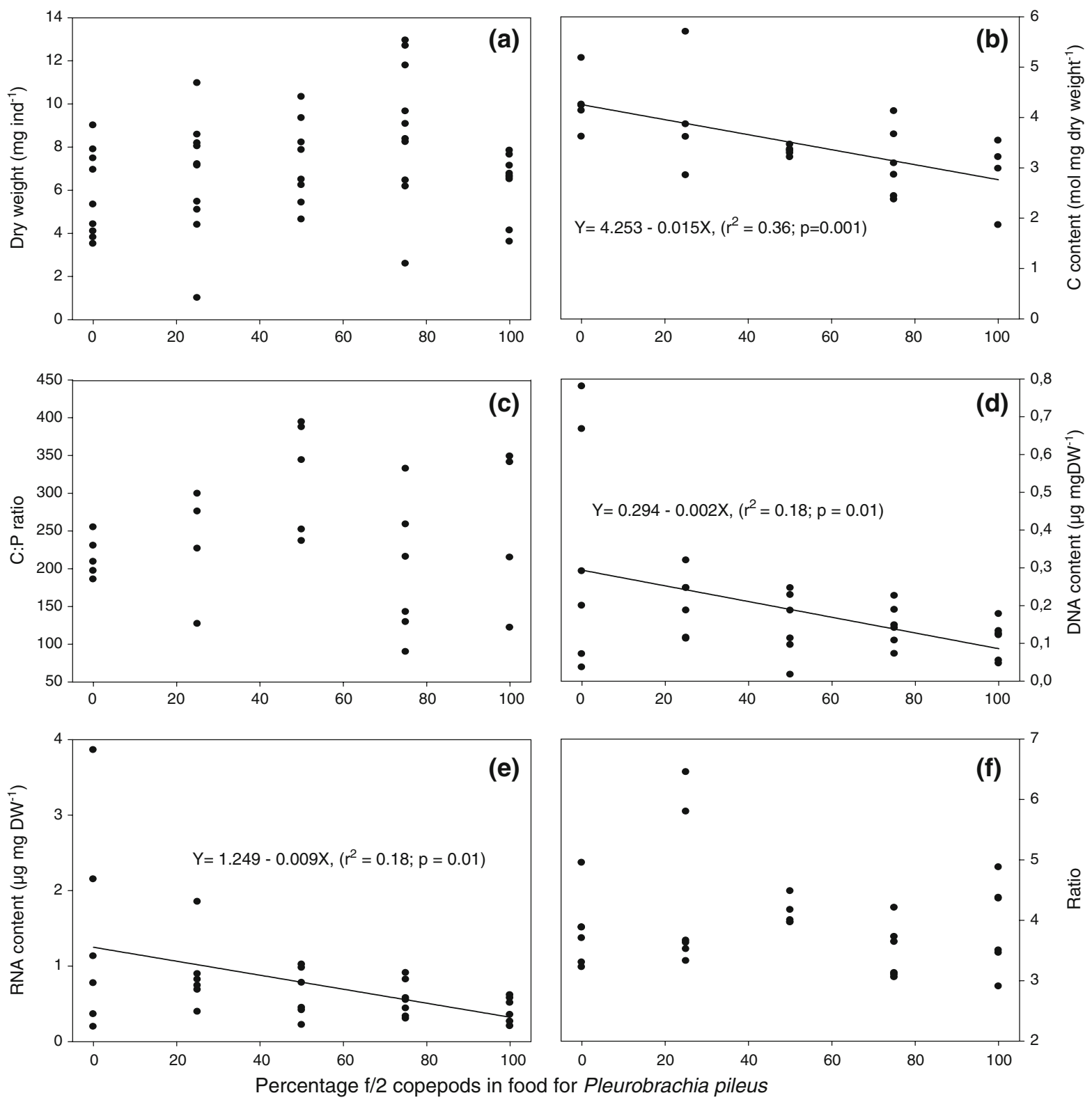

Fig. 2 Reactions of $P$. pileus to food of different $\mathrm{P}$ content. Regression lines indicate significant relationships between the percentage of $\mathrm{f} / 2$-fed copepods in the diet of $P$. pileus and the response variables. a Dry weight of $P$. pileus after the

\section{Discussion}

The classical picture in the current literature is that when going up in the food chain the C:P ratio of the organisms in each level is lower than that of the level below, as carbon is lost through respiration and incubation period; $\mathbf{b}$ carbon content (mol per mg dry weight); $\mathbf{c}$ C:P ratio (molar) of the experimental $P$. pileus; d DNA content; e RNA content; and $\mathbf{f}$ the ratio between RNA and DNA content in $P$. pileus

excretion (Sterner et al. 1998). Here, we present an unusual case where the $\mathrm{C}: \mathrm{P}$ ratio of the predator (P. pileus) actually is higher than that of the prey. As a consequence, the $f / 2$ copepods in this study may have been a lower quality food source for the predator $P$. pileus, not because they contained too much carbon 
relative to phosphorus, but rather the reverse, and it does explain why we find the best physiological condition of the $P$. pileus individuals on copepods-fed P-limited $R$. salina. Most likely, given the high C:P values of $P$. pileus, even the low-P copepods contained too much phosphorus. This excess in $\mathrm{P}$ resulted in a diet poor in carbon, making the ctenophores potentially energy limited, rather than P limited (see also Gaedke et al. 2002). So, the hypothesis based on the study of Borodkin and Korzhikova (1991), that due to their relatively high phosphorus content Pleurobrachia, or perhaps even all ctenophores, is expected to show phosphorus limitation quickly, clearly needs to be rejected. In fact, several studies (Schneider 1989; Anninsky et al. 2005) have indicated a very high content of proteins in ctenophores, which is corroborated by the low C:N values found by Kremer and coworkers (Kremer 1977, 1982; Kremer et al. 1986; Youngbluth et al. 1988), so the measurements of Borodkin and Korzhikova (1991) for Mnemiopsis leidyi might be considered unusual and not reflect a general pattern in ctenophores.

Virtually no information exists on the nutrient stoichiometry and physiology of ctenophores, and of $P$. pileus in particular. Hence, we can only speculate on the physiological processes that underlie the patterns that we have observed. Ctenophores are highly opportunistic predators that feed when possible but can withstand long periods of starvation, particularly in temperate regions (Greve 1972), and respiration rates go to virtually zero under starvation (Hamer, personal communication). The fact that these mechanisms are in place suggests that carbon limitation is not uncommon in ctenophores. Furthermore, the only study that we are aware of reporting on excretion rates of carbon and phosphorus in ctenophores (Kremer 1977) reported very high turnover rates of Mnemiopsis leidyi for phosphorus (20-50\% day $^{-1}$ ), also suggesting that phosphorus is not the limiting nutrient in ctenophores. Based on this, we would not really expect to see an effect of the changed nutrient stoichiometry, as obviously even P-limited copepods contain sufficient phosphorus to sustain an optimal physiological condition in P. pileus. We do, however, see a decrease in condition of the ctenophores with increasing phosphorus content of their prey. Boersma and Elser (2006) hypothesized that any excretion of surplus nutrients comes with a cost. Traditionally, most studies on zooplankton feeding
(Sterner and Hessen 1994; Urabe et al. 1997; DeMott et al. 1998; Sterner and George 2000; Darchambeau et al. 2003) have focused on the effect of high C:P food on growth and reproduction and explained lower performance on high C:P food with the need for the animal to rid itself of excess carbon to meet the $P$ demand. When we follow Boersma and Elser (2006) and accept that also excreting excess phosphorus comes with a cost, we can explain the patterns found in this study. Based on our results, we suggest that the phosphorus content of the $\mathrm{f} / 2$ copepods may have been too high and that the excretion of the excess phosphorus could come at the cost of a reduced physiological condition.

The analysis of the RNA and DNA contents in animals has been utilized as an indicator of the fitness and physiological condition of animals (Clemmesen et al. 2003; Melzner et al. 2005; Malzahn et al. 2007b). The method for the analysis of the RNA and DNA concentrations used here was adapted from Clemmesen et al. (2003) after the best conditions for nucleic acid extraction from ctenophore tissue were determined. Both the amount of tissue used and to a more important extent the concentration of the detergent in the buffer influenced the results. Extraction of nucleic acids from the tissue of $P$. pileus proved difficult, as the yield was very low and unstable at first. By testing a range of combinations of different sample weights and buffer concentrations, a procedure enabling a stable and consistent extraction of nucleic acids was established. The most stable and reliable results were obtained with a combination of high tissue sample weights and a reduced concentration of the buffer SDS, from the $0.01 \%$ used in the protocol established by Clemmesen et al. (2003) to $0.005 \%$. Our results show that RNA and DNA content were highly correlated $\left(r^{2}=0.98\right)$. Both the DNA content as well as the RNA content was affected in parallel as a result of the different feeding environment. Ctenophores react to adverse feeding situations by decreases in body size (Kremer 1977); the underlying mechanism to this seems to be the shedding of whole body cells (Hamer 2008), reducing the total amount of cells and including the loss of RNA and DNA contained in these cells. As a result, the ratio of RNA to DNA content in ctenophore tissue is not a very useful measure to assess physiological condition, as was already expected from the fact that body size is so plastic in ctenophores. 
Obviously, this experiment represented a very artificial world, with organisms that might not even meet in the field. However, our results have the power to reveal mechanisms that would not be visible in the field and certainly may be of relevance. Having said this, ctenophores obviously do not feed exclusively on juvenile copepods as was the case in this study. Ontogenetic changes in the nutrient stoichiometry and the phosphorus content in particular have been reported by Carrillo et al. (2001) and VillarArgaiz et al. (2002). The P content of copepods (the calanoid copepod Mixodiaptomus laciniatus) was observed to have changed over the course of the life cycle, with nauplii having a higher $\mathrm{P}$ content than adult copepods. So the results might have been different if we had used adult copepods as prey for $P$. pileus. Furthermore, 1-L bottles are certainly fairly small for P. pileus, and the organisms might have had problems developing their tentacles. However, as all experiments were carried out in the same sized vessels, this should not have been a problem.

\section{Potential implications}

By feeding the copepods to the ctenophores along a gradient, we were able to show that more subtle phosphorus limitations can also have an effect on consumers and are still traceable to the next trophic level. This is of particular importance during transitional phases in the phosphorus content of seawater, such as the late phase of a phytoplankton spring bloom in temperate regions. During this time, phytoplankton becomes more and more phosphoruslimited, and as a result the zooplankters feeding on them will also most likely change their nutrient composition to some extent. In this special case, Plimited copepods represent a food source of higher quality for $P$. pileus. Interestingly, but with a great need for further study, this period of phosphorus depletion in phytoplankton is exactly the time when we see high densities of Pleurobrachia pileus around Helgoland (Greve et al. 2004). It is possible that the ctenophores, being less vulnerable to the P-limited situation, are at an advantage during this time.

Currently, many coastal seas are undergoing reoligotrophication as a result of decreasing phosphorus inputs from the rivers (Wiltshire et al. 2008). This change in the nutrient composition towards a more phosphorus-limited regime may result in food of high quality for the ctenophores. In turn, Malzahn et al. (2007a) showed that P-deficient copepods are inferior food for zooplanktivorous larval fish, which utilize the same food source. One might speculate that this mechanism could further support the general trend towards a more gelatinous North Sea as reported by Attrill et al. (2007) as a phosphorus-limited environment would favour the occurrence of ctenophores in the plankton. Furthermore, the effects of nutritional imbalances may even be increased by rising $\mathrm{CO}_{2}$ levels, which are predicted by future climate change scenarios (IPCC 2007). This could possibly lead to changing stoichiometric composition of primary producers, which has consequences for consumers performance (Urabe et al. 2003) and might lead to higher $\mathrm{C}: \mathrm{P}$ ratios of primary producers. It has been forecast that in phosphorus-deficient systems zooplankton with high C:P ratios, such as $P$. pileus, will become more important (Gaedke et al. 2002). From this, one would predict that ctenophores will continue to grow in their importance in many coastal ecosystems.

The results presented here show that phosphorus limitations in primary producers can be traced to primary and secondary consumers. The ensuing quality effects propagate through the food web and affect higher trophic levels, albeit in a different manner than originally expected. The effects of the $\mathrm{P}$ limitation, as such, on $P$. pileus were rather weak, but the changed nutrient composition of the algae affected the secondary consumer nevertheless. Contrary to our original expectations, our results show that the ctenophore Pleurobrachia pileus is not negatively affected by low $\mathrm{P}$ food and may even benefit from a diet of copepods feeding on P-deficient phytoplankton.

Acknowledgments This study is funded by the German Science Foundation (DFG AB 289/2-1) and is part of the AWI Food Web project. We thank all colleagues in the Food Web projects and three anonymous reviewers for stimulating discussions and helpful comments to improve earlier versions of this manuscript.

\section{References}

Anninsky BE, Finenko GA, Abolmasova GI, Hubareva ES, Svetlichny LS, Bat L, Kideys AE (2005) Effect of starvation on the biochemical compositions and respiration rates of ctenophores Mnemiopsis leidyi and Beroe ovata in the Black Sea. J Mar Biol Assoc UK 85:549-561 
Attrill MJ, Wright J, Edwards M (2007) Climate-related increases in jellyfish frequency suggest a more gelatinous future for the North Sea. Limnol Oceanogr 52:480-485

Boersma M, Elser JJ (2006) Too much of a good thing: on stoichiometrically balanced diets and maximal growth. Ecology 87:1325-1330

Boersma M, Kreutzer C (2002) Life at the edge: is food quality really of minor importance at low quantities? Ecology 83:2552-2561

Boersma M, Aberle N, Hantzsche FM, Schoo KL, Wiltshire KH, Malzahn AM (2008) Nutritional limitation travels up the food chain. Int Rev Hydrobiol 93:479-488

Borodkin SO, Korzhikova LI (1991) The chemical composition of the ctenophore Mnemiopsis leidyi and its role in the nutrient transformation in the Black Sea. Okeanologiya 31:754-758

Carrillo P, Villar-Argaiz M, Medina-Sanchez JM (2001) Relationship between $\mathrm{N}: \mathrm{P}$ ratio and growth rate during the life cycle of calanoid copepods: an in situ measurement. J Plankton Res 23:537-547

Clemmesen C, Buhler V, Carvalho G, Case R, Evans G, Hauser L, Hutchinson WF, Kjesbu OS, Mempel H, Moksness E, Otteraa H, Paulsen H, Thorsen A, Svaasand T (2003) Variability in condition and growth of Atlantic cod larvae and juveniles reared in mesocosms: environmental and maternal effects. J Fish Biol 62:706-723

Daly KL (2004) Overwintering growth and development of larval Euphausia superba: an interannual comparison under varying environmental conditions west of the Antarctic Peninsula. Deep-Sea Res Part II-Top Stud Oceanogr 51:2139-2168

Darchambeau F, Faerovig PJ, Hessen DO (2003) How Daphnia copes with excess carbon in its food. Oecologia 136:336346

DeMott WR, Gulati RD, Siewertsen K (1998) Effects of phosphorus-deficient diets on the carbon and phosphorus balance of Daphnia magna. Limnol Oceanogr 43:1147-1161

Dickmann EM, Newell JM, Gonzalez MJ, Vanni MJ (2008) Light, nutrients, and food-chain length constrain planktonic energy transfer efficiency across multiple trophic levels. Proc Natl Acad Sci USA 105:18408-18412

Elser JJ, Fagan WF, Denno RF, Dobberfuhl DR, Folarin A, Huberty A, Interlandi S, Kilham SS, McCauley E, Schulz KL, Siemann EH, Sterner RW (2000) Nutritional constraints in terrestrial and freshwater food webs. Nature 408:578-580

Elser JJ, Hayakawa K, Urabe J (2001) Nutrient limitation reduces food quality for zooplankton: Daphnia response to seston phosphorus enrichment. Ecology 82:898-903

Elser JJ, Bracken MES, Cleland EE, Gruner DS, Harpole WS, Hillebrand H, Ngai JT, Seabloom EW, Shurin JB, Smith JE (2007) Global analysis of nitrogen and phosphorus limitation of primary producers in freshwater, marine and terrestrial ecosystems. Ecol Lett 10:1135-1142

Ferron A, Leggett WC (1994) An appraisal of condition measures for marine fish larvae. Adv Mar Biol 30:217-303

Fraser JH (1970) The ecology of the ctenophore Pleurobrachia pileus in scottish waters. ICES J Mar Res 33:149-168

Frost PC, Ebert D, Smith VH (2008) Responses of a bacterial pathogen to phosphorus limitation of its aquatic invertebrate host. Ecology 89:313-318
Gaedke U, Hochstadter S, Straile D (2002) Interplay between energy limitation and nutritional deficiency: empirical data and food web models. Ecol Monogr 72:251-270

Gibbons MJ, Painting SJ (1992) The effects and implications of container volume on clearance rates of the ambush entangling predator Pleurobrachia pileus (Ctenophora: Tentaculata). J Exp Mar Biol Ecol 163:199-208

Gorokhova E (2003) Relationships between nucleic acid levels and egg production rates in Acartia bifilosa: implications for growth assessment of copepods in situ. Mar Ecol Prog Ser 262:163-172

Grasshoff K, Kremling K, Ehrhardt M (1999) Methods of seawater analysis. Wiley, New York

Greve W (1970) Cultivation experiments on North Sea ctenophores. Helgol Wiss Meeresunters 20:304-317

Greve W (1972) Ökologische Untersuchungen an Pleurobrachia pileus 2. Laboruntersuchungen. Helgol Wiss Meeresunters 23:141-164

Greve W, Reiners F, Nast J, Hoffmann S (2004) Helgoland Roads meso- and macrozooplankton time-series 1974 to 2004: lessons from 30 years of single spot, high frequency sampling at the only off-shore island of the North Sea. Helgol Mar Res 58:274-288

Guillard RR, Ryther J (1962) Studies of marine planktonic diatoms. Can J Microbiol 8:229-239

Hamer H (2008) On the feeding ecology of ctenophores in the German Bight. Diploma thesis, University of Kiel

IPCC (2007) Intergovernmental panel on climate change: climate change 2007: the physical science basis. Contribution of Working Group I to the Fourth Assessment Report of the Intergovernmental Panel on Climate Change. Cambridge University Press, Cambridge

Kremer P (1977) Respiration and excretion by ctenophore Mnemiopsis leidyi. Mar Biol 44:43-50

Kremer P (1982) Effect of food availability on the metabolism of the ctenophore Mnemiopsis mccradyi. Mar Biol 71:149-156

Kremer P, Canino MF, Gilmer RW (1986) Metabolism of epipelagic tropical ctenophores. Mar Biol 90:403-412

Le Pecq JB, Paoletti C (1966) A new fluorometric method for RNA and DNA determination. Anal Biochem 17:100-107

Malzahn AM, Aberle N, Clemmesen C, Boersma M (2007a) Nutrient limitation of primary producers affects planktivorous fish condition. Limnol Oceanogr 52:2062-2071

Malzahn AM, Clemmesen C, Wiltshire KH, Laakmann S, Boersma M (2007b) Comparative nutritional condition of larval dab Limanda limanda and lesser sandeel Ammodytes marinus in a highly variable environment. Mar Ecol Prog Ser 334:205-212

Melzner F, Forsythe JW, Lee PG, Wood JB, Piatkowski U, Clemmesen C (2005) Estimating recent growth in the cuttlefish Sepia officinalis: are nucleic acid-based indicators for growth and condition the method of choice? J Exp Mar Biol Ecol 317:37-51

Parslow-Williams P, Atkinson RJA, Taylor AC (2001) Nucleic acids as indicators of nutritional condition in the Norway lobster Nephrops norvegicus. Mar Ecol Prog Ser 211:235243

Plath K, Boersma M (2001) Mineral limitation of zooplankton: stoichiometric constraints and optimal foraging. Ecology 82:1260-1269 
Reeve MR, Walter MA, Ikeda T (1978) Laboratory studies of ingestion and food utilization in lobate and tentaculate ctenophores. Limnol Oceanogr 23:740-751

Schneider G (1989) Zur chemischen Zusammensetzung der Ctenophore Pleurobrachia pileus in der Kieler Bucht. Helgol Wiss Meeresunters 43:67-76

Sterner RW, Elser JJ (2002) Ecological stoichiometry: the biology of elements from molecules to the biosphere. Princeton University Press, Princeton

Sterner RW, George NB (2000) Carbon, nitrogen, and phosphorus stoichiometry of cyprinid fishes. Ecology 81:127140

Sterner RW, Hessen DO (1994) Algal nutrient limitation and the nutrition of aquatic herbivores. Annu Rev Ecol Syst 25:1-29

Sterner RW, Clasen J, Lampert W, Weisse T (1998) Carbon: phosphorus stoichiometry and food chain production. Ecol Lett 1:146-150

Urabe J, Clasen J, Sterner RW (1997) Phosphorus limitation of Daphnia growth: is it real? Limnol Oceanogr 42:14361443

Urabe J, Togari J, Elser JJ (2003) Stoichiometric impacts of increased carbon dioxide on a planktonic herbivore. Glob Chang Biol 9:818-825 van der Zee C, Chou L (2005) Seasonal cycling of phosphorus in the Southern Bight of the North Sea. Biogeosciences 2:27-42

Van Nieuwerburgh L, Wanstrand I, Snoeijs P (2004) Growth and C:N:P ratios in copepods grazing on $\mathrm{N}$ - or Si-limited phytoplankton blooms. Hydrobiologia 514:57-72

Vermaat JE, McQuatters-Gollop A, Eleveld MA, Gilbert AJ (2008) Past, present and future nutrient loads of the North Sea: causes and consequences. Estuar Coast Shelf Sci 80:53-59

Villar-Argaiz M, Medina-Sanchez JM, Carrillo P (2002) Linking life history strategies and ontogeny in crustacean zooplankton: implications for homeostasis. Ecology 83:1899-1914

White TCR (1993) The inadequate environment. Springer, Berlin

Wiltshire KH, Malzahn AM, Kai Wirtz K, Greve W, Janisch S, Mangelsdorf P, Manly BFJ, Boersma M (2008) Resilience of North Sea phytoplankton spring blooms dynamics: an analysis of long term data at Helgoland Roads. Limnol Oceanogr 53:1294-1302

Youngbluth MJ, Kremer P, Bailey TG, Jacoby CA (1988) Chemical-composition, metabolic rates and feedingbehavior of the midwater ctenophore Bathocyroe fosteri. Mar Biol 98:87-94 